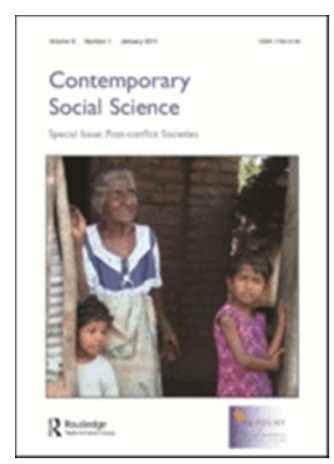

\title{
The 2016 Olympic and Paralympic Games and Brazil's soft power
}

\begin{tabular}{|r|l|}
\hline Journal: & 21st Century Society \\
\hline Manuscript ID: & RSOC-2013-0011 \\
\hline Manuscript Type: & Original Paper \\
\hline Aeywords: & Brazil, Sport, Foreign policy, Mega-events \\
\hline & $\begin{array}{l}\text { The economic growth of nations such as Brazil, Russia, India, China and } \\
\text { South Africa starred a new order into the global power balance. For Brazil, } \\
\text { winning the rights to host sport mega events gave the country recognition } \\
\text { and symbolic power in the international arena. The ensuing expectation is } \\
\text { to increase these achievements while staging the events and to sustain the } \\
\text { profits to a remarkable level of "soft power". Using the 2016 Olympic and } \\
\text { Paralympic election as a starting point, this paper aims to reveal how sport } \\
\text { has been used as a strategy of foreign policy to improve the country's soft } \\
\text { power. After reviewing some key features of the Brazilian political and } \\
\text { economic context, and the foreign policy agenda in the 2000s and the } \\
\text { 2016 election, it is shown that sport mega events support and reflect the } \\
\text { intention of many Brazilian political officials intention to increase the status } \\
\text { of Brazil in the international sphere. }\end{array}$ \\
\hline
\end{tabular}




\title{
The 2016 Olympic and Paralympic Games and Brazil's soft
}

\section{power}

\begin{abstract}
The economic growth of nations such as Brazil, Russia, India, China and South Africa starred a new order into the global power balance. For Brazil, winning the rights to host sport mega events gave the country recognition and symbolic power in the international arena. The ensuing expectation is to increase these achievements while staging the events and to sustain the profits to a remarkable level of "soft power". Using the 2016 Olympic and Paralympic election as a starting point, this paper aims to reveal how sport has been used as a strategy of foreign policy to improve the country's soft power. After reviewing some key features of the Brazilian political and economic context, and the foreign policy agenda in the 2000s and the 2016 election, it is shown that sport mega events support and reflect the intention of many Brazilian political officials intention to increase the status of Brazil in the international sphere.
\end{abstract}

Keywords: Brazil; sport; foreign policy; mega-events.

\section{Introduction}

Although the FIFA men's World Cup and the Olympic and Paralympic Games were awarded to countries from different continents in past decades, their greater magnitude and importance as media events in recent years has seen a dominance of host venues from countries considered as economically developed (Horne \& Manzenreiter 2006; Black 2007). The 2008 Beijing Olympic and Paralympic games marked the beginning of a period where mega sports events host cities were to be increasingly located in geographically new territories such as South Africa (FIFA 2010), Brazil (FIFA 2014, Summer Olympic/Paralympics 2016), Russia (Winter Olympics/Paralympics 2014, 
FIFA 2018) and Qatar (FIFA 2022). Similar diversification has been seen in those events referred to as 'second order' (Black 2008) or special events (Roche 2000), with India hosting the 2010 Commonwealth Games and Singapore the new Youth Olympic Games in 2010.

This article focuses on the ways in which Brazil has been involved in this reality of 'peripheral' mega-events bids. Specifically consideration is given to how the 2016 Olympic and Paralympic Games is being used for and reflects a strategy of foreign policy to improve the country's power position internationally through what is called 'soft power'. Before discussing this specific case, an introductory background on the recent arguments of sport governing bodies and host city/countries is presented.

The official discourse of sport governing bodies suggests that the selection of these host venues is indicative of diversification, democracy or equality. After the election of Russia and Qatar to host 2018 and 2022 FIFA World Cup for example, the president Joseph Blatter said that the event was reaching 'new lands' leading to the 'development of football' (FIFA 2010a). But some authors have argued that these statements or official justifications must be taken with caution. . Although there has been evidence of lack of transparency in the choice of host cities/countries, bribery and corruption scandals affecting FIFA and IOC (i.e. Simson \& Jennings 1992, Jennings 1996, 2006, 2011, Booth 1999, 2011, Booth \& Tatz 1994), combined with questionable outcomes for the physical and social environment surrounding the facilities, analyses of their decisions regarding host venues should take into consideration the financial reports from these events. For example, the four year period that includes the 2008 Olympics and Paralympics and the 2010 FIFA World Cup events generated respectively a revenue of US\$5.4 billion and US\$4.1 billion (FIFA 2010b: 15, IOC 2012: 6) suggesting that the award of these events to these host venues resulted in relevant economic revenues 
for these sport governing bodies. But from this amount, the support to the local organizing committees was only US\$ 226 million (4\%) and US\$ 851 million (20\%) respectively (FIFA 2010b: 18, IOC 2012: 7) while the local government investment in event-related expenditure was approximately US\$ 3.1 billion (South African Government Information 2010) and US\$ 19.68 billion (Li \& Blake 2009).

In addition to institutional discourses and profits, host cities and countries consider mega sports events as a possibility to improve their local and global images (Black \& van der Westhuizen 2004, Horne \& Manzenreiter 2006). This is not something new or exclusive to 'peripheral' countries, but the opportunity to host a major sport event enables these countries to symbolically challenge the traditional global order and identify themselves as representatives of wider emerging territories or cultures (Cornelissen 2004, Desai \& Vahed 2010, Hiller 2000). This was the case when Brazil presented the bid for the 2014 FIFA World Cup and was even more evident for the 2016 Olympic and Paralympic Games. The election for 2014 had only to confirm the sole candidate, as South America was designated the host region for the 2014 event according to the principle of continent rotation adopted by FIFA (FIFA 2007). In contrast, the election to host the 2016 Olympic and Paralympic Games involved seven candidate cities in the first phase and four in the final stage. The public involvement during the bids was considerably different. When Brazil was confirmed as host to the 2014 FIFA World Cup, the former President Luiz Inácio Lula da Silva announced that it was an opportunity to show the world the Brazilian 'growing and stable economy' (Folha Online 2007). However, his discourse to the IOC stated that the bid for the 2016 Games was not only national but regional, 'also of South America [...] a continent that never hosted the Olympic Games' (Silva 2009a). The presence of this geographically wider approach demonstrates a necessary democratisation among different global 
regions while also reinforcing market opportunities to sport organisations and their sponsors. Nevertheless, it doesn't mean that national interest was absent. On the contrary, the discourse included notions on how important the games would be for Brazil and reinforced its economic and political aspects (Idem).

Using this latter bid process for illustration, it is clear that an international project such as bidding and hosting the Olympic and Paralympic Games belongs to broader foreign policy strategies and purposes. This understanding leads us to the following sections of this paper. First we introduce the key concepts of foreign policy to discuss theoretically their relationship with sport and mega-events, drawing on Nye's (2004) conceptualisation of soft power. Second, we describe the Brazilian political and economic contexts, followed by an outline of the foreign policy agenda taking place during the two government periods of President Lula (2003-2010). Third, we provide an historical overview of past Brazilian bidding processes with an emphasis on the 2016 bid and the specific foreign policy efforts related to this action. In our closing remarks, we summarise the ways in which the Brazilian foreign policy agenda of the 2000s influenced the hosting, and ongoing preparations for, these forthcoming mega-sports events.

\section{Research rationale}

The Olympic and Paralympic Games and the FIFA World Cup are consistent with Roche's (2000: 1) conceptualisation of sports mega-events of 'large-scale cultural (including commercial and sporting) events, which have a dramatic character, mass popular appeal and international significance'. DeHanas \& Pieri (2011) suggest that the 'large-scale' nature of such events denotes their economic, visibility and symbolic characteristics, such as budget, publicity and ambition. Roche's reference to their 'dramatic character' is the broader narrative of these events that fascinates and 
stimulates audiences. This characteristic is one of the reasons for the 'appeal' to a 'mass popular' 'international' consuming audience, which generates 'significant' debates in society. Television transmission is central to the importance of mega-events as it serves as the stimulus or the means for the international visibility, enhancing the consumption by spectators (Whannel 2009), motivating sponsorship or partnership with major companies, and promoting cities and countries (Horne \& Manzenreiter 2006). Modern sporting mega-events are immersed in the broader 'interconnected world', influencing and being influenced by politics and foreign policy (Jackson \& Haigh 2009: 1). Although sport governing bodies often claim a political distance or non-intervention, they are political by their own constitution as an international nongovernmental organisation (Sugden \& Tomlinson 1998). As an independent governing body, the IOC has few restraints to its methods, but at the same time it has a valuable product, the Olympic Games, to negotiate with countries interested in hosting future events (Persson 2002). This fact is particularly important for analysing how this independent position enables an indirect interference in nation's agendas, both in national and foreign policies. In a general sense, foreign policy can be seen as 'the sum of official external relations conducted by an independent actor (usually a state) in international relations' (Hill 2003: 3). Understanding that the Olympic Games event is an international product, recognised and broadcast globally, full of apparently 'common sense' symbolic positive meanings which appeal to mass consumers, its 'political instrumentality' to foreign policy becomes evident (Cornelissen 2009: 133). By hosting or intending to host, states aim to establish and disseminate a profile to investors, tourists and other nation states, in order to mark their distinction in the global arena (Cornelissen \& Swart 2006, Cornelissen 2009). 
In order to understand how governments attempt to host mega sports events as part of a foreign policy strategy, we draw on Nye's (2004) concept of soft power. In distinguishing between hard and soft power, hard power is understood as that forced upon people by violent, militaristic and/or economic ends. In contrast, soft power is often viewed as power achieved when people, institutions or nation states accept the authority of others as normal by way of culture, politics or policies (what Bourdieu referred to as symbolic power or Foucault as the consequence of panoptic surveillance) (see Blommaert 2008, Nye 2004). Conceptually then, soft power 'is the ability to get what you want through attraction rather than coercion or payments.' (Nye 2004: x). For example, after the London 2012 Games, the concept of soft power was used to describe how people around the world had their views regarding the United Kingdom influenced by the presentation of British culture, values, sporting institutions and the environment (see Worne 2012). Indeed, the development of soft power was a direct legacy aim for London 2012, with plans to build influential relationships with other countries by way of a global public diplomacy campaign which included specially commissioned films, events and activities (see DCMS 2010). From this campaign, the World Shakespeare Festival was part of the Cultural Olympiad promoted from 2008 to London 2012, and had performances of Shakespeare's plays in 37 languages and in 35 countries (Garcia 2013), which demonstrates further possibilities for cultural diplomacy (see Cull, 2008).

Both powers are not directly proportional, which means that a country or institution can concentrate on one of them but not the other and use them according to the context. As a consequence, they are supposed to be managed jointly by states that aim to succeed on the international stage (Nye 2004, 2008), in what can be called 'smart power' (see also Wilson 2008). Soft power is not synonymous with public diplomacy, as the latter refers to actions for interfering in external behaviour and the former also 
includes internal actions and policies (Nye 2008). Soft power is also historically constructed, dependent on the perception of policies and actions by others, and so it is rare that a solo action is capable of promoting considerable changes. Manzenreiter (2010) extends this position to argue that there is an overrated notion of the power of sport mega-events and especially the Olympics to improve a country's image.

Such concerns regarding the potential offered by hosting a mega sports event for increasing soft power are taken in consideration by any host city, but this debate seems to be especially problematic to rising economic powers such as Brazil, Qatar, India and China. Quoting Nye (2008: 95): 'if the content of a country’s culture, values, and policies are not attractive, public diplomacy that "broadcasts" them cannot produce soft power'. For example, in the preparations for the 2010 Commonwealth Games, there were extensive images of poverty, pollution and corruption in India (Carter 2011), while prior to the 2008 Olympic and Paralympic Games images abounded of China's poor record on human rights issues, quality of manufacturing and environmental awareness (Manzenreiter 2010). But, for example, worldwide opinion polls suggest that the image of China did not improve subsequent to their hosting of the 2008 Beijing Olympic and Paralympic Games (Manzenreiter 2010) Although the 'aura' (in a common sense) or the discourses lead many to believe that the Olympic Games are favorable for image enhancement, to what extent they are favorable is still an open question. So if past image problems are not ignored or forgotten, the Olympic Games have been used to present alternative stories (Cull 2011). How to deal with this past image or how to present culture, values and politics accepted by an international audience are further challenges for future mega-events hosts, and also for these countries' foreign policy if they intend to be more than an economic and/or military power. The next section illustrates how Brazil is dealing with these challenges. 


\section{Brazil, foreign policy and the 2016 Olympic and Paralympic Games}

Brazil is the $5^{\text {th }}$ largest country in the world in area and in population (199 million people in 2012). It has borders with ten of twelve South American countries. The economy reached the $8^{\text {th }}$ biggest GDP in 2011 and is based on services $(67 \%)$, industry $(27.5 \%)$ and agriculture (5.5\%). The main trade partners are China, the USA and Argentina, followed by Germany, the Netherlands and South Korea. The country is a federative republic, having secured independence from Portugal since 1822 and the current Federal Constitution was approved in 1988. Presidential elections have been held every four years since 1985, and voting is compulsory for all citizens aged from 18 to 70 years-old. The national political headquarter is located in the capital Brasília, a city that was planned and built in the 1950s. Before this, Rio de Janeiro used to be the Brazilian capital and it is currently the second largest city, behind São Paulo (CIA 2012).

The events that we are analysing in this paper took place during the period that Luiz Inácio Lula da Silva was Brazil's President. He was elected in 2002, starting his first term in 2003 and then re-elected in 2006. His government finished in the year of 2010, leaving the presidency to the candidate of his party, Dilma Rousseff. As a result of these elections, there has been consistency in the political leadership and ideology regarding foreign policy during the bidding process for the 2016 Olympic and Paralympic Games.

\section{Reaching the 'international citizenship'}

In order to understand the specific strategies of Brazilian foreign policy, we will briefly sketch its position in the international socio-political-economic order. It is generally accepted that the current global order includes a multi-state region, the European Union (EU), and single power states not strongly articulated with their region, most notably as 
the United States. The rising role of other countries have been given attention in recent decades as a result of globalization processes (Cervo 2010), and direct and indirect challenges to the USA and EU hegemonic position (perhaps most notably in the ' $9 / 11$ ' attacks on the USA followed by similar events in Europe which many regarded as a direct challenge to the global order) (Hurrell 2008, Flemes 2010).

A key strategy of the Lula government's foreign policy was to attempt to coordinate governance with these - North-South cooperation - and other countries South-South cooperation (Lima \& Hirst 2006, Hurrell 2006, 2008, Cervo 2010, Almeida 2010, Visentini \& Silva 2010, Amorim 2007). Brazil doesn't confront the military power of other nations, but has strategically invested in flexible alliances with other countries in global institutions (i.e. World Trade Organization-WTO, International Monetary Fund-IMF and United Nations-UN). This soft balancing behaviour consists of having flexible relations with hegemonic powers in many areas but uses non-military instruments to limit or harm their unilateral positioning (Flemes 2010, see also Pape 2005). The relatively peaceful behaviour is mostly because Brazilian territory disputes ended 100 years ago, since when there has been greater preoccupation with the economy and development (Lima \& Hirst 2006). Its military expenditures were $1.7 \%$ of the GDP in 2009, a smaller percentage than those invested by United States, China, Russia, India, South Korea, France and United Kingdom, for example (CIA 2012).

Within these global forums, the Brazilian main agenda is to democratise the decision process through institutionalised coordination with other developing countries, such as IBSA (India, Brazil and South Africa) and the G-20 (the group of 20 major economies) (Visentini \& Silva 2010). Although BRIC has surged as analytical concept, currently the relationships between these four nations are only of an informal political alliance and coordination (Flemes 2010). Vigevani \& Cepaluni (2007) describe this 
strategy as 'autonomy by diversification', in which the cooperation between SouthSouth would balance more traditional relations with Northern countries. The perspective of multilateralism has been considered as a historical pillar since the creation of the United Nations (Lima \& Hirst 2006).

According to the former Minister of Foreign Affairs Celso Amorim (20032010), Brazil maintains a position of peaceful attitudes through the multilateral debate to solve conflicts, to protect human rights and to promote the sustainable development respecting states' sovereignty (Amorim 2007). From this positioning, Brazil has been working to expand the UN Security Council and become a permanent member since 2003 (Visentini \& Silva 2010, Sotero 2010, Lima \& Hirst 2006, Vigevani \& Ramanzini Júnior 2011). According to the former Ministry of Foreign Affairs (2003-2010), Brazil's case is grounded in its historical involvement as a founding member of the UN, the continuous involvement in humanitarian expeditions and commissions, the selective representation of the current countries and a 'natural' leadership of Brazil in South America (Amorim 2007).

While all these arguments are subject to criticisms from domestic and regional authors and politicians, such as in Argentina, Colombia and other smaller states (Almeida 2010), the regional leadership is particularly controversial. Some authors understand that Brazil was not effective as a regional leader during the Lula government (Malamud 2011, Almeida 2010). Vigevani et al (2008) argue that regional integration is still a foreign policy strategy objective but is no longer a priority. We believe that there may have been political interest in regional relations but that there is not from the national elites, for whom the needs or profits of this integration are questionable. While regional integration and Brazil's position as regional leader was not reinforced in Lula's government, the rise of Brazil in a global sense is nonetheless generally accepted 
(Malamud 2011, Almeida 2010, Sotero 2010, Cervo 2010, Hurrell 2008). Accordingly, while some advocate that the country has asserted its interests in the international sphere (Malamud 2011, Cervo 2010, Sotero 2010, Hurrell 2008), others believe that Brazil's status is not recognized internationally yet (Almeida 2010). Among the challenges and risks to improving Brazil's status in international affairs, there are: lack of regional support, conflicting interests with strategic partners, lower growth in GDP and decrease in the international trade participation (Malamud 2011, Almeida 2010, Sotero 2010).

Despite these criticisms or the supposed inefficiency of these strategies, Brazil presented Rio de Janeiro's bid to host the 2016 Olympic and Paralympic Games displaying itself as a rising power both economically and politically in international forums. The next section details how Brazil built past bids but particularly how the country managed the 2016 bid. Moreover, it articulates how foreign affairs strategies established the main tools to conquer votes and confidence of other countries until the 2009 IOC choice of Rio de Janeiro, as well as influencing the Brazilian Government to fully support of the 2016 bid.

\section{The pursuit of sport international events}

Brazil had a representative in the 'founding' group of the Modern Olympics and has been constantly represented in the IOC (Abreu et al 2006). This close relationship with the Olympic movement from an early stage explains why Brazil first considered hosting the Olympic Games in 1936. However, in the latter part of the 1920s, the Brazilian economy was mainly based on coffee exportation, and so the New York stock exchange crisis of 1929 prevented forward movements to officially present the bid (Rubio 2010). The second time Brazil considered bidding to host the Games was at the end of the 1980s to host the games in 2000 in Brasília, as a celebration for its 40th anniversary. However, this was a politically unstable period with the president facing an 
impeachment process in 1991. For this reason, Brazil withdrew from the bidding before the IOC meeting. The third attempt, which was the first that became a real bid, was in the 1990s to host the Olympic Games of 2004 in Rio de Janeiro (Idem). Carlos Arthur Nuzman was the president of the Brazilian Olympic Committee and remains in this position at the time of writing (Abreu et al 2006). However, according to the Brazilian authorities, the lack of experience of hosting big sportive events was one of the reasons why its bid wasn't accepted by the IOC (Brasil 2007). In 2002 the Brazilian Olympic Committee won the bid to host the Pan American Games of 2007. The year prior to this, Brazil submitted its second Olympic bid in 2006 to host the 2012 Games on the basis that some sport facilities would be developed for the Pan American Games which would strengthen their bid. However, once again, Brazil was eliminated before the second round of voting (Rubio 2010).

Finally, the fifth attempt and third formal bidding process was initiated in 2008, one year after the Pan American Games in Rio de Janeiro. For the 2016 Olympic and Paralympic Games, the IOC received seven bids from Rio de Janeiro (Brazil), Tokyo (Japan), Chicago (USA), Madrid (Spain), Prague (Czech Republic), Baku (Azerbaijan) and Doha (Qatar). For the first time, Brazil went into the second round of voting with Tokyo, Chicago and Madrid (IOC 2008). In the 121st IOC session in Copenhagen, the IOC president Jacques Rogge announced Rio as host of the 2016 Olympic Games after beating in three rounds of voting Chicago, Tokyo and Madrid, in this order. The Brazilian delegation was composed of the Brazilian President Luiz Inácio Lula da Silva among other political figures from federal and local government, Olympic and Paralympic athletes.

The 2016 Rio de Janeiro's bid was initiated by the Brazilian Olympic Committee and received the support of the three levels of government: the city of Rio 
de Janeiro, the state of Rio de Janeiro and the Brazilian federal government. This support is not only explicit in the opening letters of the bid books, but throughout all bid documents. According to them, the Olympic and Paralympic Games would fit into the city's long term plan by boosting its transformation through the creation of a new urban structure and promoting social inclusion. In this sense, the proposed vision was "the Games of celebration and transformation" (Comitê de Candidatura 2009: 2).

By celebration, the bid committee understands that athletes would perform sporting excellence in high profile facilities in a beautiful city with a joyful atmosphere. The celebration would happen together with a transformation of Rio de Janeiro in social, urban and environmental areas and bringing international recognition and visibility to Brazil and its resilient economy. For these purposes, the bid committee and the government set five key strategies: to promote the participation of youth; to bring social transformation and development through sport; to establish the country as a South American sport leader; to promote the country globally; and to deliver the Games successfully (Comitê de Candidatura 2009). It is noteworthy that the third and fourth strategies are directly linked to Brazilian foreign policy. Regarding the sport regional leadership, the training sport facilities would attract South American athletes as the "main economic potency" in the region that has the "means, opportunity and vocation to use sport as a tool to help its neighbours". The country's promotion would be the consequence of the mega-event's visibility as a touristic destination and "to reinforce its status of important economy in booming growth" (Comitê de Candidatura 2009: 20).

Following the initial section outlining the motivation for hosting the Games, the documents reiterate the proposal to reach a South American audience and make reference to the economic power of Brazil. This repetition appears to extend beyond simply the Brazilian government's will. A geographical argument was raised by the 
Brazilian bid, as the Games have never previously been hosted by a South American country and the other three bidding countries already had hosted them. This differential was reinforced during the bid presentation at the IOC voting session (Silva 2009a; UOL Esporte 2009). The economic guarantee has been a major concern in past decades considering the IOC's demands of financial support to build the structure needed to host the event (Horne \& Whannel 2012). In the bid period (2008 and 2009), this concern was stronger considering the world financial crisis and the historical instability of the Latin American countries (see Ocampo 2009). Reference to the economic growth and inflation rates, market size and future projections were presented, but evidence of current and future investments supporting the bid and potentially the Games have permeated all the documents (Comitê de Candidatura 2009). This agenda was simultaneously an advantage and incentive for the Brazilian government to use the bid project in its foreign policy aims, or vice-versa.

The final election was considered a victory for Brazilian self-esteem, as defeating other global powers in the bid process had a symbolic meaning.. In the press conference right after the election, President Lula said: 'I'm sorry for being happy and you [to President Obama and Zapatero and to the Prime Minister Hatoyama] sad, but you were happy and we were sad many times. We are allowed to be happy today and you added value to our dispute' (Silva 2009b). Then, a journalist asked President Lula what he felt about beating president Obama (of the USA and whose home city is Chicago) in the first voting round. In his answer, President Lula said that it wasn't about him and Obama, but about two proposals organised by the cities (Silva 2009b). However, the posing of this question demonstrated that the significance for Brazil was more than just the right to host the event. Moreover, the declared meaning of this election was: 
'This victory for me is: Brazil won, definitely, its international citizenship. We are not second class, we are first class, no one is better neither worst, may be equal. This is how we want to be and this is what this victory means.' (Silva 2009b)

As this speech extract shows, in relation to the Brazilian foreign policy presented above, the bid and election for 2016 are part of a wider socio-political issue. Carlos Resende (2010) presents further data on how sport and foreign policy were coordinated during Lula's presidency. In 2004, President Lula asked the Brazilian Football Confederation to play a friendly game in Haiti labelled as "The match of the peace". Immediately prior to this event, the Brazilian seleção had just won the 2002 FIFA World Cup and well-known football players not only played but also appeared publicly in armoured vehicles of the UN. On this occasion, Brazil was investing in the political situation of Haiti and intended to show a positive message through football. Later in 2008, a general-coordination of sport interchange and cooperation was created inside the Ministry of Foreign Affairs. The main reasons for that were: the demand from developing countries to cooperate in sport and specially football; the choice of Brazil as host of the 2014 FIFA World Cup; and the bid for the 2016 Olympic and Paralympic Games.

Resende (2010) cites many agreements with various countries. Generally, infrastructure, legacy and security knowledge were imported and football coaching knowledge and material were exported (Resende 2010, Vasconcellos 2011). The majority of these agreements were between 2008 and 2010. Resende (2010) explains that all the Brazilian Embassies during the bid phase were informed about the Olympic bid, instructed to mention it in every public event and supported any Brazilian sport delegation abroad. The diplomats were expected to contact IOC voting members, presidents of international federations and National Olympic Committees, government 
authorities and sportspeople that could influence the choice of Rio de Janeiro to host the 2016 Games. Besides that, President Lula attended the opening ceremony in Beijing 2008 and visited the sites of the London 2012 Games during 2009. After the IOC election, numerous agreements on planning, organisation, legacy and economic areas were signed with the United Kingdom, Germany and South Africa and others were being developed with Australia, Canada, United States and Russia (Resende 2010).

The role of the Brazilian government's Ministry of Foreign Affairs in coordinating activities to enhance the image of Brazil demonstrates the significance of mega sporting events and how they are part of a broader foreign policy agenda. According to the organizational structure of this Ministry in Brazil, it is likely that this decision-making took place in cabinet diplomacy that includes authorities in high hierarchical positions such as the President of Republic, the Ministry of Foreign Affairs, State Secretary and others sub-secretaries (Figueira 2010). Leveraging the country's image is not only to attract tourists or business, but to position itself as a rising economic power and as a regional leader that intends to have a political role in a global arena. This is certainly a key concern for Brazilian politics in order to establish not only a provisional impact but to build a positive legacy. If legacy is not seen as a natural positive consequence of hosting a major sporting event, it is possible to identify how 'soft power' is a possible 'positive legacy' from the mega-events hosted in Brazil. Thus, as Preuss (2007) argues, there are multiple dimensions of legacies which include tangible and intangible facets of both planned and unplanned occurrences, all of which are subject to positive and negative outcomes from the events themselves and wider related activities.

Resende (2010) shows that those coordinating the Brazilian government's activities were aware about the international criticism and lack of confidence of how the 
games were delivered in China and India. For this reason, activities and strategies are being put in practice to increase confidence in the Brazilian capacity to host mega sporting events. So, the foreign affairs involvement is not only related to the delivery of the events, but also influences the decision process on what image should be presented to the wider international audience. The main intention is to show Brazil as an established democracy with a sustainable economic growth (Resende 2010). The president's discourse during the IOC session that voted for Rio de Janeiro as 2016 host city reinforces this assumption:
'Brazil lives an excellent momentum. We work hard in the past decades. We have an organized and thriving economy that faced without shock the financial crisis, which still disrupts many nations. We live an environment of freedom and democracy. In the past 30 years, 30 million Brazilians left the poverty threshold and 21 million now integrate the new middle class. Overcoming difficulties is the mark of the recent history of Brazil and the trajectory of millions of Brazilians. I have just participated at the G-20 summit in Pittsburgh, where it was drawn by consensus a new economic global map. This map recognizes the importance of rising powers as Brazil in the global scenario and, moreover, in overcoming the financial crisis. I am proud, as Brazilian, to be engaged in this process and to see Brazil as part of the solution.' (Silva 2009a)

\section{Final remarks}

Of all of the international sport events hosted by Brazil to date, the 1950 FIFA World Cup is possibly the most important. As the first World Cup after the Second World War, Brazil had only two years of preparation, while politicians and media saw the possibility of showing different images of Brazil and Brazilian cities abroad (Fraga 2006; Lise et al 2010). The main idea of hosting that event was to show Brazilian modernity through civility, organization and urban growth to the world, while simultaneously reinforcing these images and a patriotic feeling among the domestic public (Fraga 2006). Similarly, 
despite historical, political and cultural differences, Tokyo 1964 (Aso 2002), Mexico

City 1968 (Brewster \& Brewster 2006) and Seoul 1988 (Seh-Jik 1991) also attempted to display such images along with their national economic growth.

Looking to the past, it is possible to notice some similarities on how major sporting events were and are being used to deliver political messages and images in Brazil. But this is not a Brazilian novelty, as we indicated in the introduction to this article based on the literature of mega-events. Unique aspects of this case are the recent magnitude and impact of mega-events, plus the new dynamic and challenges of an 'emerging power' hosting two of them in a short period of time - 2014 FIFA World Cup and 2016 Olympic and Paralympic Games.

To discuss how these events are linked to a broader foreign policy agenda, a conceptual background was introduced before the presentation of specific data on the Brazilian foreign policy and its relation to the bidding process for 2016. It was shown that the main objective of the Brazilian foreign policy agenda (2003-2010) was to position the country among the global leaders and the soft power was used as one of the main instruments. In summary, soft power is the historically constructed capacity of conquering power (status, position, evidence, influence, distinction) in the international arena through non-coercive internal and external actions and policies in culture, political values and foreign policy. Brazil is promoting it through: multilateralism, coordination for governance, humanitarian involvement to establish its position in the $\mathrm{UN}$ and regional leadership.

Sport in the Brazilian foreign policy agenda confirms national values and interests, generates business and projects a positive image internationally (Vasconcellos 2011). In other words, the Brazilian 'ball diplomacy', as Resende (2010) proposes, is based on three pillars: 
'[T]he Brazilian embassies increase the number of interlocutors; sport, and particularly football, has social appeal; and the actions have visibility in the national and international media. The ball diplomacy can be understood as a tool of the Brazilian soft power.' (Resende 2010: 41)

From a central coordination, the embassies advocate on a subject of interest in different countries and football is a Brazilian cultural appropriation that has possibility for international exchange, frequently reaching media attention. Somehow, these practices resemble the last four of the five elements of Cull's (2008) public diplomacy taxonomy: listening, advocacy, cultural diplomacy, exchange diplomacy and international broadcasting. Sport and particularly football as a public diplomacy focused on foreign audiences, to influence their perceptions as Nye (2008) has differentiated - works to improve soft power. Incorporated in this agenda, mega-events were seen as a possibility to reinforce and establish new multilateral relations, to reflect economic and political conquests in both the domestic and global level through these international platforms, to promote peace through sport and to present Brazil as a leading representative of South America. After all, winning the 2016 bid when the other candidate cities were from more established global powers was a way to position oneself for a domestic and international audience, in symbolic and discursive spheres, among the international leaders. If the idea of a 'bidding war' (Tomlinson \& Sugden 2002) can be applied to illustrate a mean of accumulating soft power in a hard power metaphor, the recent election to host the 2016 Olympic and Paralympic Games by itself can be considered a positive outcome in the Brazilian strategy.

How this coordination will be seen or if the enhancement of image or a incorporation of soft power will be 'legacies' of the mega-events in Brazil, only future studies can say. At the same time, risks and challenges on how the international audience will perceive these efforts have been identified by Brazilian officials. What 
this article intended to show is that the 'political instrumentality' of sport mega-events are being used in Brazil among a broader foreign policy strategy of accumulating soft power. Consequently, the effects of staging them should be contextualized in future analyses of hosting sport mega-events.

\section{Acknowledgements:}

This research was developed while two of the authors were receiving scholarship from the CAPES Foundation, Ministry of Education of Brazil -- Processes n. 9443/12-6 and n. 1105/11-6, respectively.

\section{References}

Abreu, N, Hecksher, R, Franceschi, M, Rajman, B (2006) Comitê Olímpico Brasileiro COB. In: Dacosta, L (org.). Atlas do Esporte no Brasil. Rio de Janeiro: CONFEF.

Almeida, P (2010) Never before seen in Brazil: Luis Inácio Lula da Silva’s grand diplomacy. Revista Brasileira de Política Internacional, 53 (2): 160-177.

Amorim, C (2007) A diplomacia multilateral do Brasil: um tribute a Rui Barbosa. Brasília: Fundação Alexandre de Gusmão e Instituto de Pesquisa de Relações Internacionais.

Aso, N (2002) Sumptuous Re-past: The 1964 Tokyo Olympics Arts Festival. Positions: East Asia Cultures Critiques, 10 (1): 7-38.

Black, D \& van der Westhuizen, J (2004) The allure of global games for 'semiperipheral' polities and spaces: a research agenda. Third World Quarterly, 25 (7), 1195-1214.

Black, D (2007) The symbolic politics of sport mega-events: 2010 in comparative perspective. Politikon, 34 (3): 261-276.

Black, D (2008) Dreaming big: the pursuit of 'second order' games as a strategic response to globalization. Sport in Society, 11 (4), 467-480.

Blommaert, J (2008). Notes on power. Working paper on language diversity. Jyväskylä: University of Jyväskylä. 
Booth D (1999) Gifts of corruption: The gift in the olympic movement. Olympika 9: $43-68$.

Booth D (2011) Olympic city bidding: An exegesis of power. International Review for the Sociology of Sport, 46 (4): 367-386.

Booth D and Tatz C (1994) 'Swimming with the big boys': The politics of Sydney's 2000 Olympic bid. Sporting Traditions 11(1): 3-23.

Brasil (2007) Relatório sobre os XV Jogos Pan-americanos e os III Jogos Parapanamericanos realizados no Rio de Janeiro em 2007, v. 1. Available at:

$<$ http://www.esporte.gov.br/arquivos/publicacoes/panVolume1.pdf $>$. Accessed on: 14 feb. 2013.

Brewster, C \& Brewster K (2006) Mexico City 1968: Sombreros and Skyscrapers. In: Tomlinson, A \& Young, C. National identity and global sports events: culture, politics and spectacle in the Olympics and the football World Cup. Albany: State University of New York Press.

Carter, T (2011) Interrogating athletic urbanism: On examining the politics of the city underpinning the production of the spectacle. International Review for the Sociology of Sport, 46 (2): 131-139.

Cervo, A (2010) Brazil's rise on the international scene: Brazil and the world. Revista Brasileira de Política Internacional, 53 (SE): 7-32.

CIA (2012) The World Factbook - Brazil. Available at: $<$ https://www.cia.gov/library/publications/the-world-factbook/geos/br.html $>$. Accessed on: 11 dec. 2012.

Comitê de Candidatura (2009). Dossiê de candidatura do Rio de Janeiro a sede dos Jogos Olímpicos e Paraolímpicos de 2016, v. 1. Rio de Janeiro: Comitê de Candidatura.

Cornelissen, S (2004) 'It's Africa's Turn!' The narratives and legitimations surrounding the Moroccan and South African bids for the 2006 and 2010 FIFA finals. Third World Quarterly, 25 (7), 1293-1309.

Cornelissen, S (2009). Scripting the nation: sport, mega-events, foreign policy and statebuilding in post-apartheid South Africa. In: Jackson, S \& Haigh, S (eds) (2009). Sport and foreign policy in a globalizing world. London and New York: Routledge. 
Cornelissen, S \& Swart, K (2006) The 2010 Football World Cup as a political construct: the challenge of making good on an African promise. Sociological Review, 54: $108-23$.

Cull, N (2008) Public diplomacy: taxonomies and histories. The ANNALS of the American Academy of Political and Social Sciences, 616: 31-54.

Cull, N (2011) The public diplomacy of the modern Olympic Games and China's soft power strategy. In: Price, M \& Dayan, D (eds) Owning the Olympics: narratives of the new China. 4 ed. Ann Arbor: University of Michigan Press.

DCMS (2010) Plans for the legacy from the 2012 Olympic and Paralympic Games. December 2010. Available at $<$ http://www.culture.gov.uk/images/publications/201210_Legacy_Publication.p df>. Accessed on: 14 feb. 2013.

Dehanas, D N \& Pieri, Z (2011) Olympic Proportions: The Expanding Scalar Politics of the London 'Olympics Mega-Mosque’ Controversy. Sociology 45 (5): 798-814.

Desai, A \& Vahed, G (2010) World Cup 2010: Africa's turn or the turn on Africa? Soccer \& Society, 11 (1-2), 154-167.

FIFA (2007) 'Brazil confirmed as 2014 hosts.' News, 30 October 2007 available at: http://www.fifa.com/worldcup/news/newsid=625695/index.html accessed 8 March 2012.

FIFA (2010a). Russia and Qatar awarded 2018 and 2022 FIFA World Cups. News, 02 December 2010. Available at: < http://www.fifa.com/worldcup/russia2018/news/newsid=1344698/index.html >. Accessed on 10 dec. 2012.

FIFA (2010b) FIFA Financial Report 2010. Available at: $<$ http://www.fifa.com/mm/document/affederation/administration/01/39/20/45/w eb_fifa_fr2010_eng[1].pdf $>$. Accessed on: 10 dec. 2012.

Figueira, A (2010) Rupturas e continuidades no padrão organizacional e decisório do Ministério das Relações Exteriores. Revista Brasileira de Politica Internacional 53 (2): 5-22.

Flemes, D (2010) O Brasil na iniciativa BRIC: soft balancing numa ordem global em mudança? Revista Brasileira de Política Internacional 53 (1): 141-156.

Folha Online (2007) 'Lula quer que Copa-2014 mostre crescimento econômico do Brasil.' 30 October 2007. Available at: 
http://www1.folha.uol.com.br/folha/esporte/ult92u341088.shtml accessed 8 March 2012.

Fraga, G. W. (2006) Onde os jacarés não andam pelas ruas: a imprensa e os motivos da realização da Copa do Mundo de 1950 no Brasil [Where alligators dont walk on the streets: the media and reasons to host the 1950 World Cup in Brazil]. Biblos, $20,145-156$.

Garcia, B (2013) London 2012 Cultural Olympiad Evaluation. Liverpool: Institute of Cultural Capital. Available at $<$ http://www.artscouncil.org.uk/media/uploads/pdf/london_2012_academic_rep ort/London_2012_Cultural_Olympiad_Evaluation_ICC.pdf $>$. Accessed on 05 June 2013.

Hill, C (2003) The changing politics of foreign policy. Basingstoke: Palgrave Macmillan.

Hiller, H (2000) Mega-Events, Urban Boosterism and Growth Strategies: An Analysis of the Objectives and Legitimations of the Cape Town 2004 Olympic Bid. International Journal of Urban and Regional Research, 24 (2), 439-458.

Horne, J \& Manzenreiter, W (2006) An introduction to the sociology of sports megaevents. Sociological Review, 54 (2) 1-24.

Horne, J \& Whannel, G (2012) Understanding the Olympics. London: Routledge.

Hurrell, A (2006) Hegemony, liberalism and global order: what space for would-be great powers? International Affairs, 82 (1): 1-19.

Hurrell, A (2008) Lula's Brazil: a rising power, but going where? Current History, 107 (706): 51-57.

IOC (2008) Games of the XXXI Olympiad 2016 working group report. 14 mai. 2008. Available at:

$<$ http://www.olympic.org/Assets/ImportedNews/Documents/en_report_1317.pdf >. Accessed on: 10 dec. 2012.

IOC (2012) Olympic Marketing Fact File 2012. Available at: < http://www.olympic.org/Documents/IOC_Marketing/olympic-marketing-factfile-2012.pdf $>$. Accessed on: 10 dec. 2012.

Jackson, S \& Haigh, S (eds) (2009). Sport and foreign policy in a globalizing world. London and New York: Routledge.

Jennings A (1996) The New Lords of the Rings. London: Pocket Books. 
Jennings A (2006) Foul! The secret world of FIFA: bribes, vote rigging and ticket scandals. London: Harper Sport.

Jennings A (2011) Investigating corruption in corporate sport: The IOC and FIFA. International Review for the Sociology of Sport, 46 (4): 387-398.

Li, S \& Blake, A (2009) Estimating Olympic-related Investment and Expenditure. International Journal of Tourism Research, 11 (4): 337-356.

Lima, M \& Hirst, M (2006) Brazil as an intermediate state and regional power: action, choice and responsibilities. International Affairs, 82 (1): 21-40.

Lise, R.; Mosko, J.; Santos, N.; Capraro, A. (2010). Copa do Mundo de 1950: a imprensa e os jogos realizados em Curitiba [1950 World Cup: the media and the matches in Curitiba]. Esporte e Sociedade, 5 (14), 1-10.

Malamud, A (2011) A Leader without Followers? The Growing Divergence Between the Regional and Global Performance of Brazilian Foreign Policy. Latin American Politics and Society 53(3): 1-24.

Manzenreiter, W (2010). The Beijing Games in the Western Imagination of China: The weak power of soft power. Journal of Sport and Social issues, 34 (1): 29-48.

Nye, J (2004). Soft power: the means to succeed in world politics. New York:

PublicAffairs.

Nye, J (2008). Public diplomacy and soft power. The ANNALS of the American Academy of Political and Social Science, 616 (1): 94-109.

Ocampo, José Antonio (2009) Latin America and the global financial crisis. Cambridge Journal of Economics, 33 (4): 703-724.

Pape, R (2005) Soft Balancing against the United States. International Security, 30 (1): $7-45$.

Persson, C (2002) The Olympic Games Site Decision. Tourism Management 23 (1): 2736.

Preuss, H (2007) The Conceptualisation and Measurement of Mega Sport Event Legacies, Journal of Sport \& Tourism, 12 (3-4), 207-228.

Resende, C (2010). O esporte na Política externa do Governo Lula: o importante é competir? Meridiano 47, 11 (122): 35-41.

Roche, M (2000) Mega-events and modernity: Olympics and expos in the growth of global culture. New York: Routledge. 
Rubio, K (2010). Postulações brasileiras aos Jogos Olímpicos: considerações acerca da lenda do distanciamento entre política e movimento olímpico. Biblio $3 \mathrm{~W}$. Revista Bibliográfica de Geografía y Ciencias Sociales, 15 (895): 1-22.

Seh-Jik, P (1991). The Seoul Olympics: the inside story. London: Bellew Publishing.

Silva, L (2009a) Discurso do Presidente da República, Luiz Inácio Lula da Silva, na sessão de apresentação da Candidatura Rio 2016 ao Comitê Olímpico Internacional (COI). Copenhagen, Denmark, October 02nd 2009. Available at $<$ http://www.itamaraty.gov.br/sala-de-imprensa/discursos-artigos-entrevistas-eoutras-comunicacoes/presidente-da-republica-federativa-dobrasi1/147730942008-discurso-do-presidente-da-republica-luiz-inacio>. Accessed on 10 dec. 2012.

Silva, L (2009b) Entrevista coletiva concedida a jornalistas brasileiros e estrangeiros pelo Presidente da República, Luiz Inácio Lula da Silva, após o anúncio da escolha da cidade-sede dos Jogos Olímpicos de 2016. Copenhagen, Denmark, October 02nd 2009. Available at <http://www.itamaraty.gov.br/sala-deimprensa/discursos-artigos-entrevistas-e-outras-comunicacoes/presidente-darepublica-federativa-do-brasil/entrevista-coletiva-concedida-a-jornalistas $>$. Accessed on 12 dec. 2012.

Simson V and Jennings A (1992) The Lords of the Rings. Power, Money \& Drugs in the Modern Olympics.

Sotero, P (2010) Brazil's rising ambition in a shifting global balance of power. Politics, 30 (S1): 71-81.

South African Government Information (2010) 2010 FIFA World Cup ${ }^{\text {TM }}$. Available at: $<$ http://www.info.gov.za/issues/world_cup/index.htm>. Access on: 14 feb. 2013.

Sugden, J \& Tomlinson, A (1998) FIFA and the contest for world football: who rules the people's game? Cambridge: Polity Press.

Tomlinson, A \& Sugden, J (2002) International power struggles in the governance of world football: the 2002 and 2006 World Cup bidding wars. In: Horne, J \& Manzenreiter, W (eds) Japan, Korea and the 2002 World Cup. London: Routledge.

UOL Esporte (2009) Nuzman pede ao COI realização de Jogos na América do Sul. EFE Redação Central, 02 oct. 2009. Available at http://esporte.uol.com.br/ultimas/2009/10/02/ult1777u113059.jhtm Access on 18 Feb. 2013. 
Vasconcellos, D (2011) Esporte, Poder e Relações internacionais. 3. ed. Brasília: Fundação Alexandre de Gusmão.

Vigevani, T \& Cepaluni, G (2007) A política externa de Lula da Silva: a estratégia de autonomia pela diversificação. Contexto Internacional, 29 (2): 273-335.

Vigevani, T \& Ramanzini Júnior, H (2011) The impact of Domestic Politics and international changes on the Brazilian perception of regional integration. Latin American Politics and Society, 53 (1): 125-155.

Vigevani, T, Favaron, G, Ramanzini Júnior, H \& Correia, R (2008) O papel da integração regional para o Brasil: universalismo, soberania e percepção das elites. Revista Brasileira de Política Internacional, 51(1): 5-27.

Visentini, P \& Silva, A (2010) Brazil and the Economic, Political. And Environmental multilateralism: the Lula years (2003-2010). Revista Brasileira de Politica Internacional, 53(SE): 54-72.

Whannel, G (2009) Television and the Transformation of Sport. The ANNALS of the American Academy of Political and Social Science, 625: 205-218.

Wilson, Ernest (2008) Hard power, soft power, smart power. The ANNALS of the American Academy of Political and Social Science, 616: 110-124.

Worne, J. (2012) Britain's Gold Medal in Soft Power. Huffington Post, November 21st 2012. 